\title{
Laju Penurunan Suhu Terhadap Kualitas Semen Beku Sapi Limousin Menggunakan Medium Pengencer Susu Segar dan Tris Kuning Telur
}

\section{Cooling Rate on the Quality of Frozen Thawed Semen of Limousin Bull Using Fresh Milk and Tris Yolk Extender}

\author{
L. Suhartati*, Z. Udin, dan Rizqan \\ Fakultas Peternakan Universitas Andalas, Padang, Sumatera Barat - Indonesia \\ *Corresponding E-mail: lindasuhartati@ansci.unand.ac.id \\ (Diterima: 12 April 2020; Disetujui: 20 Juli 2020)
}

\begin{abstract}
ABSTRAK
Penelitian ini bertujuan untuk mengetahui kualitas semen beku sapi Limousin terhadap interaksi laju penurunan suhu pembekuan dengan dua medium pengencer. Metode penelitian menggunakan eksperimental dengan Rancangan Acak Kelompok (RAK) pola faktorial (2x3) dengan 3 kelompok, sebagai faktor A adalah medium pengencer (A1: Susu Segar dan A2: Tris Kuning Telur), dan sebagai faktor B adalah laju penurunan suhu pembekuan (B1: $15^{\circ} \mathrm{C} /$ menit, B2: $10^{\circ} \mathrm{C} /$ menit, $\mathrm{B} 3: 5^{\circ} \mathrm{C} /$ menit). Hasil Penelitian medium pengencer pada faktor A2 memperlihatkan hasil terbaik dengan rataan motilitas $(43,86 \pm 4,58 \%)$, persentase hidup spermatozoa $(53,33 \pm 6,08 \%)$, abnormalitas spermatozoa $(14,67 \pm 0,88 \%)$, MPU $(41,53 \pm 2,90 \%)$. Hasil penelitian laju penurunan suhu pembekuan pada faktor B2 memperlihatkan hasil terbaik dengan rataan motilitas $(45,10 \pm 4,85 \%)$, persentase hidup spermatozoa $(52,58 \pm 7,89 \%)$, abnormalitas spermatozoa $(14,42 \pm 0,59 \%)$, dan MPU $(42,25 \pm 2,47 \%)$. Analisis sidik ragam memperlihatkan adanya interaksi yang sangat nyata $(\mathrm{P}<0,01)$ antara susu segar dan tris kuning telur sedangkan kecepatan penurunan suhu $\left(15^{\circ} \mathrm{C} /\right.$ menit, $10^{\circ} \mathrm{C} /$ menit dan $5^{\circ} \mathrm{C} /$ menit) terhadap rataan motilitas, persentase hidup spermatozoa, dan membran plasma utuh setelah pembekuan dan tidak berbeda nyata $(\mathrm{P}<0,05)$ terhadap abnormalitas spermatozoa. Kesimpulan penelitian ini adalah medium pengencer tris kuning telur dengan laju penurunan suhu pembekuan $10^{\circ} \mathrm{C} /$ menit menunjukkan motilitas, persentase hidup, dan MPU yang terbaik.
\end{abstract}

Kata kunci: sapi Limousin, laju penurunan suhu, medium pengencer, kualitas semen beku

\section{ABSTRACT}

This study aims to determine the quality of frozen semen of Limousin cattle on the interaction of the freezing temperature reduction rate with two extenders. The experimental design used was a factorial randomized block design (RBD) with three groups, as factor A was the extender (A1: Fresh milk and A2: tris yolk), and as factor $B$ was the rate of freezing temperature decrease (B1: 150C/minute, B2: 100C/minute, B3: 50C/minute). The results of extender research on factor A2 showed the best results with averaged motility (43.86 $\pm 4.58 \%)$, percentage of spermatozoa life (53.33 $\pm 6.08 \%)$, spermatozoa abnormalities $(14.67 \pm 0.88 \%) \mathrm{MPU}(41.53 \pm 2.90 \%)$. The results of the freezing temperature reduction rate on factor $B 2$ showed the best results with average motility $(45.10 \pm 4.85 \%)$, percentage of spermatozoa life $(52.58 \pm$ $7.89 \%)$, abnormalities of spermatozoa (14.42 $\pm 0.59 \%)$, Membrane Integrity (42.25 $\pm 2.47 \%)$. The results of the freezing temperature reduction rate on factor $B 2$ showed the best results with average motility (45.10 $\pm 4.85 \%)$, percentage of spermatozoa life (52.58 $\pm 7.89 \%)$, abnormalities of spermatozoa (14.42 $\pm 0.59 \%)$, Membrane Integrity $(42.25 \pm 2.47 \%)$. Analysis of variance showed a very significant difference $(P<0.01)$ between fresh milk and tris yolk while the speed of temperature reduction (150C/minute, 100C/minute, and $50 \mathrm{C} /$ minute) to the mean motility, live percentage of spermatozoa, and membrane Integrity after freezing and not significantly different $(P<0.05)$ to spermatozoa abnormalities. This research concludes that the tris yolk extender with a freezing temperature reduction rate of 100C/minute shows the best motility, life percentage, and Membrane Integrity. 
Keywords: limousine cattle, temperature decrease speed, extender, frozen semen quality

\section{PENDAHULUAN}

Pembekuan semen merupakan proses pengeringan secara fisik di bawah titik beku. Mumu (2009) menyatakan bahwa terciptanya kristal es diakibatkan terjadi nya penumpukan cairan elektrolit beserta bahan terlarut yang terdapat didalam sel. Secara mekanik kristal es yang terbentuk dapat merusak sel spermatozoa, sedangkan selubung lipoprotein pada dinding sel spermatozoa dapat larut yang diakibatkan berlebihnya konsentrasi elektrolit, dimana pada saat dilakukan thawing permeabilitas membran selnya akan berubah dan mengakibatkan kematian sel. Hal tersebut mengindikasikan bahwajenis bahan pengencer yang digunakan dapat mempengaruhi kualitas semen beku pasca thawing. Kuning telur dan air susu mengandung lipoprotein dan lecithin. Menurut Muhilal dan Sulaiman (2004) menyatakan bahwa kuning telur dan air susu mengandung lipoprotein dan lecithin dapat berperan sebagai pelindung bagi spermatozoa dari cold shock dan melindungi integritas selubung lipoprotein dari sel spermatozoa. Kandungan glukosa, protein dan viskositas pada kuning telur sangat menguntungkan bagi spermatozoa (Surhayati dan Hartono, 2011). dengan begitu kedua bahan tersebut dapat dijadikan sebagai bahan pengencer.

Proses kecepatan penurunan suhu saat proses pembekuan semen juga mempengaruhi kualitas semen beku pasca thawing. Kecepatan penurunan suhu $16^{\circ} \mathrm{C} /$ menit pada media sitrat kuning telur lebih tinggi $(50,17 \%)$ jika dibandingkan pada media laktosa kuning telur $(45,23 \%)$ terhadap Motilitas dan keutuhan akrosom spermatozoa. Kwon (2002) menyatakan pembekuan pada suhu $24^{\circ} \mathrm{C} /$ menit lebih rendah dibandingkan pada suhu $16^{\circ} \mathrm{C} /$ menit pada media laktosa-kuning telur terhadap keutuhan akrosom. Selanjutnya motilitas dan keutuhan akrosom spermatozoa yang dibekukan dengan menggunakan tris kuning telur pada suhu $7,25^{\circ} \mathrm{C} /$ menit (Lambat) dan $13,3^{\circ} \mathrm{C} /$ menit (Sedang) menunjukkan hasil yang sama yaitu 56,6\% akan tetapi lebih tinggi jika dibandingkan dengan suhu $30,9^{\circ} \mathrm{C} /$ menit (Cepat) sehingga ditemukan laju penurunan suhu optimum sekitar $13^{\circ} \mathrm{C} /$ menit (Kwon, 2002).

Herdiawan (2004) menyatakan bahwa laju penurunan suhu, kadar krioprotektan dan jenis bahan pengencer, serta komponen lainnya berinteraksi sangat erat dalam mempengaruhi kualitas semen yang dibekukan. Dengan demikian setiap terjadi perlakuan laju penurunan suhu pembekuan dengan jenis bahan pengencer yang berbeda akan memberikan respon terhadap kualitas semen beku yang berbeda pula.

\section{METODE}

\section{Tempat Penelitian}

Penelitian ini dilakukan di Laboratorium Balai Inseminasi Buatan Tuah Sakato, Payakumbuh dan Laboraturium Bioteknologi Ternak, Fakultas Peternakan Universitas Andalas.

\section{Materi Penelitian}

Materi yang digunakan dalam penelitian ini adalah semen dari sapi Limousin yang berjumlah 1 ekor dan berumur 3 tahun ditampung dengan vagina buatan yang dipelihara di Balai Inseminasi Buatan Tuah Sakato, Payakumbuh dengan frekuensi penampungan 1 kali dalam 1 minggu.

\section{Rancangan Penelitian}

Penelitian ini menggunakan Rancangan Acak Kelompok (RAK) pola faktorial (2x3) dengan 3 Kelompok penampungan semen segar, sebagai faktor A adalah medium pengencer (A1: Susu Segar dan A2: Tris Kuning Telur), dan sebagai faktor B adalah laju penurunan suhu pembekuan $\left(\mathrm{B} 1: 15^{\circ} \mathrm{C} /\right.$ menit, B2: $10^{\circ} \mathrm{C} /$ menit, B3: $5^{\circ} \mathrm{C} /$ menit) (Steel and Torrie, 1991).

\section{Pelaksanaan Penelitian}

Tahapan penelitian yaitu: a) 
Penampungan semen dilakukan dengan menggunakan vagina buatan; b) Evaluasi semen segar secara makroskopis (Volume, Warna, Konsistensi, pH, Bau) dan mikroskopis (Gerakan Massa, Konsentrasi, Motilitas, Persentase Hidup, Abnormalitas, Membran Plasma Utuh Spermatozoa); c) Pembuatan bahan pengencer susu segar dengan komposisi: Susu segar $100 \mathrm{ml}$, Penisilin $1 \times 10^{3} \mathrm{IU}$, Streptomycin $1 \mathrm{mg} /$ $\mathrm{ml}$, dan Pengencer tris kuning telur dengan komposisi: Tris aminomethan 3,634 g, Sitrat $2,17 \mathrm{~g}$, Penisilin $1 \times 10^{3} \mathrm{IU}$, Streptomycin $1 \mathrm{mg} /$ $\mathrm{ml}$, Aquadestilata $100 \mathrm{ml}$, Kuning telur $20 \mathrm{ml}$ (Udin et al., 2013); d) Gliserolisasi: sebanyak $6 \%$ bahan pengencer yaitu $6 \mathrm{ml}$ dikeluarkan kemudian tambahkan kekosongan dengan gliserol sebanyak $6 \%$ yaitu $6 \mathrm{ml}$ kedalam bahan pengencer dan bahan pengencer dicampur dengan semen; e) Setelah semen di evaluasi, semen dilakukan pengenceran dengan tris kuning telur dan pengencer susu segar. Semen diencerkan dengan mengandung $10^{7}$ spermatozoa yang hidup per ml-nya (Feradis, 2010); f) Printing straw; g) Filling dan Sealing (Pengisian Straw); h) Ekuilibrasi dan Pendinginan: Pendinginan yaitu penurunan suhu secara perlahan dari $37^{\circ} \mathrm{C}$ menuju $5^{\circ} \mathrm{C}$ yang dilakukan didalam cool top, semen diekuilibrasi selama 4 jam; h) Pembekuan semen dilakukan dengan menggunakan alat Ice Cube versi minitube. Alat ice cube dihidupkan lalu diisikan freezing program dengan kecepatan penurunan suhu $15^{\circ} \mathrm{C} /$ menit, $10^{\circ} \mathrm{C} /$ menit, dan $5^{\circ} \mathrm{C} /$ menit. Kemudian straw dimasukkan kedalam alat ice cube dan dilakukan pembekuan dari suhu $4^{\circ} \mathrm{C}$ menuju suhu $-120^{\circ} \mathrm{C}$. Setelah itu straw diambilan dimasukkan kedalam kontainer berisi $\mathrm{N}_{2}$ cair, dan dibiarkan minimal selama 9 menit hingga semen memiliki suhu $-196^{\circ} \mathrm{C}$; i) Thawing dilakukan dengan menggunakan air hangat pada temperature $370 \mathrm{C}$ selama 30 detik (Feradis, 2010); dan j) Evaluasi Setelah Thawing secara mikroskopis.

\section{Peubah yang diamati}

Peubah yang diamati yaitu: a) Motilitas progresif pasca thawing: Pengamatan motilitas spermatozoa dilakukan dengan meneteskan satu tetes semen yang telah diencerkan dengan $\mathrm{NaCl}$ fisiologis pada objek glass. Perbandingan untuk semen sapi yaitu 1:4. Kemudian diperiksa dibawah CASA (Computerized Assisted Sperm Analyzed). CASA akan mendeteksi secara otomatis sperma yang bergerak motil dan ditampilkan dalam bentuk persen (Arifiantini, 2012); b) Abnormalitas pasca thawing (Toelihere, 1993); c) Persentase hidup pasca thawing (Susilawati, 2011): dan d) Membran Plasma Utuh Spermatozoa (Arifiantini, 2012).

\section{HASIL DAN PEMBAHASAN}

\section{Karakteristik Semen Segar Sapi Limousin Sebelum Perlakuan}

Hasil evaluasi secara makroskopis dan mikroskopis semen segar sapi Limousin yang ditampung selama penelitian dari satu ekor sapi Limousin jantan di BIB Tuah Sakato Payakumbuh dapat dilihat pada Tabel 1. Penilaian Volume semen sapi Limousin yang didapatkan adalah sebagai berikut $6,3 \mathrm{ml}$, 4,6 $\mathrm{ml}$ dan 5,0 $\mathrm{ml}$ dengan rata-rata 5,3 $\pm 0,89$ $\mathrm{ml}$. Hasil yang didapatkan tergolong kategori normal dengan rentang 5-8 $\mathrm{ml}$ (Feradis, 2010) dan 7,17-7,20 ml (Denilisvanti et al., 2017). Warna semen yang diperoleh dalam penelitian ini yaitu berwarna krem keputih-putihan. Hal ini sesuai dengan pendapat Feradis (2010) bahwa semen sapi normal berwarna seperti susu atau krem keputih-putihan dan keruh yang masih tergolog normal menurut Wahyudi et al. (2016) dimana warna semen sapi yaitu: krem keputihan (warna susu).

Konsistensi semen yang diperoleh selama penelitian tergolong dalam kategori sedang. Menurut Toelihere (1993) semen sapi dengan konsistensi sedang mempunyai konsentrasi 1000 per ml. Hasil yang didapatkan sama dengan pendapat Zulyazaini et al. (2016) dimana konsistensi semen pada sapi aceh berkisar dari sedang sampai kental.

Nilai $\mathrm{pH}$ dan Bau yang didapatkan tergolong normal, karena sesuai dengan $\mathrm{pH}$ 
Tabel 1. Rataan Makroskopis dan Mikroskopis Semen Segar Sapi Limousin

\begin{tabular}{lcccc}
\hline \multirow{2}{*}{ Penilaian } & \multicolumn{3}{c}{ Penampungan } & \multirow{2}{*}{ Rataan } \\
\cline { 2 - 4 } & 1 & 2 & 3 & \\
\hline Makroskopis & & & & $5,3 \pm 0,89$ \\
Volume (ml) & 6,3 & 4,6 & 5,0 & KP \\
Warna & $\mathrm{KP}$ & $\mathrm{KP}$ & $\mathrm{KP}$ & Sedang \\
Konsistensi & Sedang & Kental & Sedang & 7 \\
pH & 7 & 7 & 7 & $\mathrm{~N}$ \\
Bau & $\mathrm{N}$ & $\mathrm{N}$ & $\mathrm{N}$ & \\
& & & & \\
Mikroskopis & & & & ++ \\
Gerakan Massa & ++ & ++ & ++ & $207,33 \pm 30,35$ \\
Konsentrasi (107) & 180,00 & 240,00 & 202,00 & $82,17 \pm 2,08$ \\
Spermatozoa Hidup (\%) & 80,50 & 84,50 & 81,50 & $80,30 \pm 1,35$ \\
Motilitas (\%) & 79,00 & 81,70 & 80,20 & $11,17 \pm 0,76$ \\
Abnormalitas (\%) & 12,00 & 10,50 & 11,00 & $80,33 \pm 1,04$ \\
MPU (\%) & 79,50 & 81,50 & 80,00 & \\
\hline
\end{tabular}

Keterangan: $\mathrm{KP}=$ Krem Keputih-putihan, $\mathrm{N}=$ Normal, $++=$ Sedang

semen sapi segar umumnya yaitu $6,4-7,8$ (Sunami et al., 2017; Garner dan Hafez, 2008) serta Bau amis dan anyir merupakan bau normal pada semen menurut Afriantini (2012). Gerakan massa yang didapatkan termasuk kategori baik $(++)$. Hal tersebut memenuhi syarat kualitas semen segar menurut Yahaq et al. (2019) dan Feradis (2010) gerakan massa yang baik $(++)$ terlihat gelombang-gelombang kecil, tipis, jarang, kurang jelas dan bergerak lamban.

Konsentrasi semen yang diperoleh tergolong baik dengan rataan 207,33 $\pm 30,35$ spermatozoa per $\mathrm{ml}$. hasil yang didapatkan sesuai dengan pendapat Lestari et al. (2013) bahwa konsentrasi sapi Limousin 93,33\% rata-rata pejantan memiliki konsentrasi lebih dari $1.000 \mathrm{juta} / \mathrm{ml}$.

Persentase spermatozoa hidup yang didapatkan masih memenuhi standar dengan rataan $82,17 \pm 2,08 \%$. Hasil ini selaras dengan pendapat Hafez (2000) semen segar yang akan diproses lanjut seharusnya mengandung spermatozoa hidup minimal $80 \%$. Motilitas yang diperoleh selama penelitian masih tergolong kategori baik dengan rataan $80,30 \pm 1,35 \%$. Motilitas yang didapatkan lebih tinggi di bandingkan dari hasil penelitian
Lestari et al. (2013) yaitu dengan rata-rata 67,56\%, Muada et al. (2017) yaitu 59,29\%, dan Coester et al. (2019) yaitu 75,00\%.

Abnormalitas spermatozoa yang diperoleh masih termasuk kedalam kategori baik dengan rataan $11,17 \pm 0,76 \%$. Dimana batas abnormalitas spermatozoa tidak lebih dari 15\% (Ax et al., 2010). Membran plasma utuh spermatozoa yang diperoleh masih termasuk kedalam kategori baik dengan rataan $80,33 \pm 1,04 \%$. Hal ini sesuai dengan pendapat Arifiantini (2012) menyatakan bahwa kategori semen infertil yaitu kurang dari $60 \%$.

\section{Evaluasi Kualitas Semen Beku Sapi Limousin Pasca-Thawing}

Rataan persentase motilitas untuk jenis bahan pengencer tris kuning telur $(43,86 \pm 4,58)$ memiliki hasil lebih tinggi dibandingkan dengan susu segar $(39,04 \pm 2,49)$. Kecepatan penurunan suhu $10^{\circ} \mathrm{C} /$ menit menunjukkan motilitas tertinggi yaitu $(45,10 \pm 4,85)$ dibandingkan dengan kecepatan penurunan suhu lainnya (Gambar 1).

Rataan spermatozoa hidup lebih tinggi dibandngkan spermatozoa motil (Gambar 2). Spermatozoa yang hidup belum tentu motil, tetapi sejumlah spermatozoa yang tidak motil 


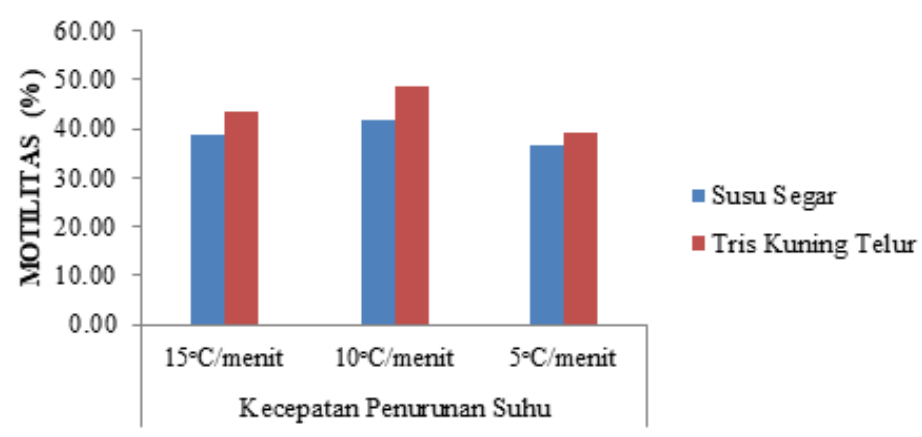

Gambar 1. Rataan persentase motilitas pada dua macam bahan pengencer dengan tiga kecepatan penurunan suhu pembekuan pada semen sapi Limousin

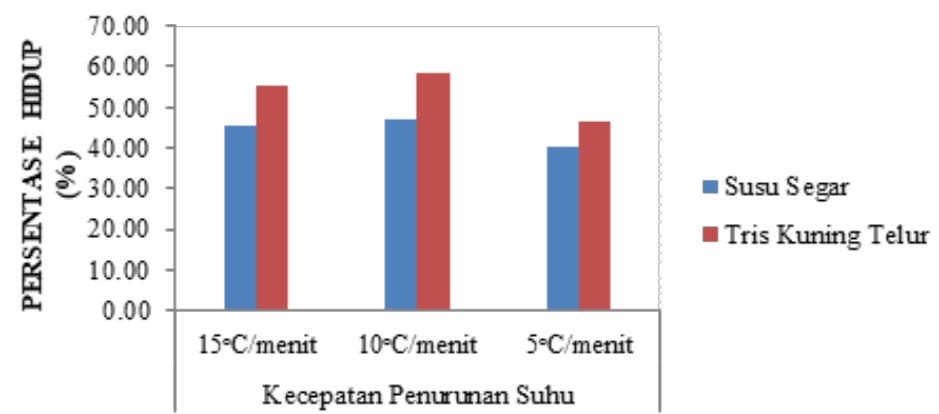

Gambar 2. Rataan persentase spermatozoa hidup pada dua macam bahan pengencer dengan tiga kecepatan penurunan suhu pembekuan pada semen sapi Limousin

terkadang masih hidup (Campbell et al., 2003). Berdasarkan hasil penelitian, persentase hidup spermatozoa yang menggunakan jenis bahan pengencer tris kuning telur $(53,33 \pm 6,08)$ lebih tinggi dibandingkan dengan bahan pengencer susu segar $(44,39 \pm 3,43)$. Pada kecepatan laju penurunan suhu $10^{\circ} \mathrm{C} /$ menit memiliki rataan persentase spermatozoa hidup tertinggi dibandingkan dengan kecepatan penurunan suhu $5^{\circ} \mathrm{C} /$ menit $(50,50 \pm 6,83)$ dan $15^{\circ} \mathrm{C} /$ menit $(43,50 \pm 4,24)$.

Bahan pengencer pengencer tris kuning telur $(14,67 \pm 0,88)$ memiliki persentase abnormalitas spermatozoa lebih rendah dibandingkan dengan penggunaan bahan pengencer susu segar $(15,50 \pm 0,67)$ (Gambar $3)$. Kecepatan penurunan suhu pembekuan $10^{\circ} \mathrm{C} /$ menit mendapatkan persentase abnormalitas terendah yaitu $(14,42 \pm 0,59)$ dibandingkan dengan dua kecepatan suhu lainnya, yaitu kecepatan penurunan suhu pembekuan $15^{\circ} \mathrm{C} /$ menit $(14,92 \pm 0,82)$ dan $10^{\circ} \mathrm{C} /$ menit $(15,92 \pm 0,35)$. Menurut Salamon dan Maxwell (1995) bahan pengencer tris kuning telur dapat mencegah tekanan osmotik yang hipotonik pada membrane sel yang dapat menyebabkan membengkoknya leher spermatozoa. Sehingga kelainan morfologi spermatozoa bisa menjadi lebih rendah.

Perlakuan dengan menggunakan Tris kuning telur $(41,53 \pm 2,90)$ memiliki hasil Membran Plasma Utuh (MPU) spermatozoa lebih tinggi dibandingkan dengan Susu segar $(37,61 \pm 2,63)$. Rataan kecepatan penurunan suhu pembekuan $10^{\circ} \mathrm{C} /$ menit $(42,25 \pm 2,47)$ mendapatkan persentase membran plasma utuh tertinggi, diikuti dengan kecepatan penurunan suhu pembekuan $15^{\circ} \mathrm{C} /$ menit $(39,63 \pm 3,72)$ dan $5^{\circ} \mathrm{C} /$ menit $(36,83 \pm 2,12)$ (Gambar 4).

Berdasarkan hasil evaluasi kualitas semen beku sapi Limousin pasca-thawing penggunaan bahan pengencer tris kuning telur dengan kecepatan penurunan suhu pembekuan $10^{\circ} \mathrm{C} /$ menit menunjukkan hasil terbaik. Kandungan glukosa yang terdapat

Laju Penurunan Suhu Terhadap ... (Suhartati et al.) 


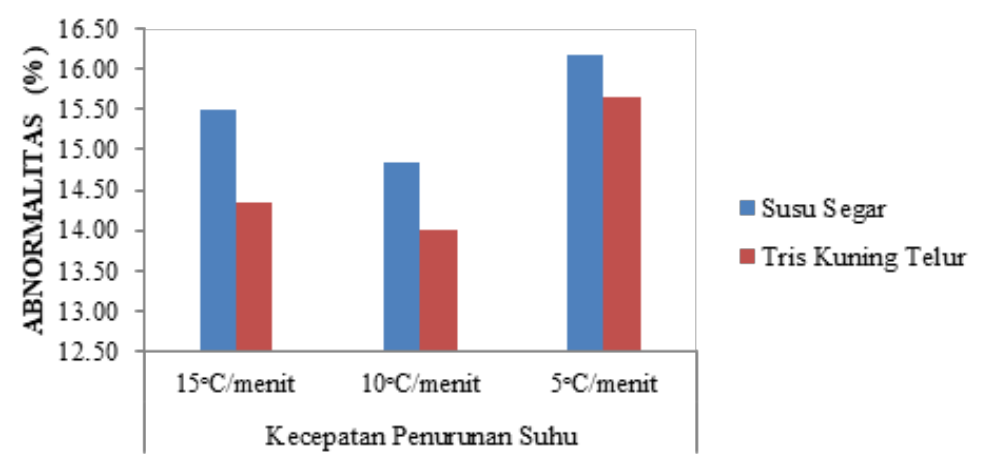

Gambar 3. Rataan persentase abnormalitas spermatozoa pada dua macam bahan pengencer dengan tiga kecepatan penurunan suhu pembekuan pada semen sapi Limousin

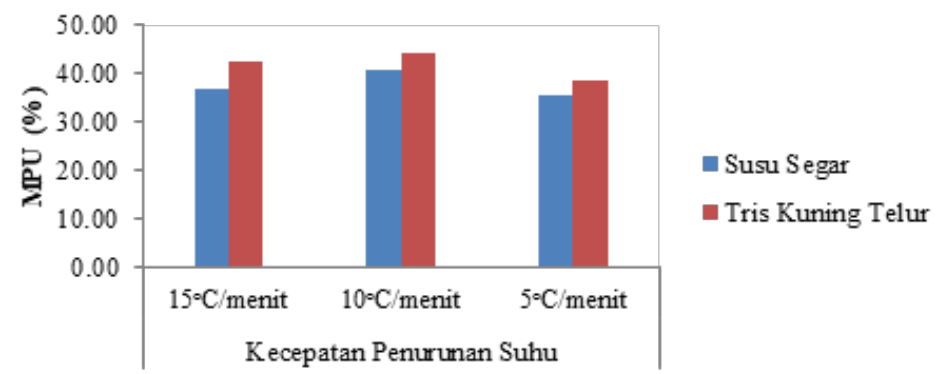

Gambar 4. Rataan persentase membran plasma utuh spermatozoa pada dua macam bahan pengencer dengan tiga kecepatan penurunan suhu pembekuan pada semen sapi Limousin

pada kuning telur dimanfaakan oleh sel spermatozoa untuk melakukan proses metabolisme (Toelihere, 1993). Selain itu telur juga mengandung protein, lemak, garam dan air yang dapat menambah energi spermatozoa pada saat pengenceran. Gazali (2002) juga menambahkan bahwa manfaat kuning telur terletak pada kemampuannya mempertahankan dan melindungi integritas selubung lipoprotein sel spermatozoa. Sel spermatozoa menjadi lebih toleran terhadap pengencer hipotonik dan hipertonik yang berfungsi sebagai perlindungan terhadap penurunan suhu secara drastis.

Bahan pengencer tris kuning telur memiliki titik beku lebih rendah sebesar $\left(-15^{\circ} \mathrm{C}\right)$ bila dibandingkan dengan pengencer susu segar $\left(-0,5^{\circ} \mathrm{C}\right)$. Perbedaan titik beku tersebut berhubungan erat dengan kecepatan laju penurunan suhu dan proses pembentukan kristal-kristal es, serta tingkat keseimbangan tekanan osmotik. Hal ini sebagai akibat adanya perbedaan konsentrasi elektrolit intraseluler dan ekstraseluler (Herdiawan, 2004).

Perbedaan titik beku pada jenis pengencer tersebut menyebabkan kerusakan sel secara fisik maupun kimia lebih tinggi. Hal ini terjadi karena percepatan pembentukan kristal-kristal es dengan ukuran lebih kasar yang menyebabkan dehidrasi. Proses dehidrasi terjadi karena adanya pengeluaran cairan intraseluler yang mengakibatkan keseimbangan tekanan osmotik intraseluler dan ekstraseluler terganggu. Sehingga sel spermatozoa mengalami kerusakan secara fisik maupun kimia. Mekanisme pembentukan kristal-kristal es pada pengencer tris-kuning telur, terjadi lebih lambat dan memiliki ukuran kristal yang lebih halus (Herdiawan, 2004) dibandingkan dengan bahan pengencer susu segar.

Pada kecepatan penurunan suhu $10^{\circ} \mathrm{C} /$ menit, integritas spermatozoa masih dapat dipertahankan dengan baik. Hal ini sama dengan penelitian Farhana et al. (2018) dan Sagita (2015) yang menyatakan bahwa 
kecepatan penurunan suhu pada $10^{\circ} \mathrm{C} /$ menit memiliki persentase motilitas, spermatozoa hidup, dan membrane plasma utuh tertinggi pada semen beku pasca-thawing sapi Bali dan sapi Brahman.

Supriatna dan Fachriyan (1992) menyatakan bahwa kerusakan sel spermatozoa terjadi pada metode lambat. Pada metode pembekuan lambat, air yang keluar cukup banyak untuk mencapai keseimbangan potensial kimiawi intra dan ekstraseluler. Sehingga sel mengalami dehidrasi, konsentrasi larutan intraseluler meningkat, dan spermatozoa menjadi rusak. Sedangkan jika sel spermatozoa dibekukan dengan metode cepat, keseimbangan potensial kimiawi intra dan ekstraseluler akan terganggu. Mekanisme pembekuan ini menyebabkan sel tidak mampu mengeluarkan air dengan cepat sehingga kristal es dapat merusak integritas sel yang menyebabkan melemahnya daya gerak, bahkan dapat menyebabkan kematian sel spermatozoa.

\section{KESIMPULAN}

Berdasarkan hasil Penelitian ini dapat disimpulkan bahwa laju penurunan suhu pembekuan dengan medium pengencer tris kuning pada suhu $10^{\circ} \mathrm{C} /$ menit menunjukkan hasil yang terbaik dalam mempertahankan kualitas semen sapi limousin di Balai Inseminasi Buatan Tuah Sakato, Payakumbuh, Sumatera Barat.

\section{DAFTAR PUSTAKA}

Arifiantini, R. L. 2012. Teknik Koleksi dan Evaluasi Semen pada Hewan. Institut Pertanian Bogor. Bogor.

Ax, R. L., M. Dally., B. A. Didion., R. W. Lenz, and C. C. Love. 2008. Semen Evaluation in Farm Animal Reproduction.Baltimour. 25: 365-375.

Campbell, J. R., M. D. Kenealy, and K. L. Campbell. 2003. Animal Science. 4th Ed. New York: Mc Graw-Hill.
Coester, J. S., A. Sulaiman, dan M. Rizal. 2019. Daya Hidup Spermatozoa Sapi Limousin yang Dipreservasi dengan Pengencer Tris dan Berbagai Konsentrasi Sari Kedelai. Jurnal Ilmu dan Teknologi Peternakan Tropis. 6(2): 175-180.

Denilisvanti, B., Muada., U. Paputungan., M. J. Hendrik, dan S. H. Turangan. 2017. Karakteristik Semen Segar Sapi Bangsa Limousin dan Simmental di Balai Inseminasi Buatan Lembang. Jurnal Zootek. 37(2): 360 - 369.

Farhana, A., Zaituni. U., Jaswandi., Riyan, and N. A. 2018. Effect of Extender and Cooling Rate on the Quality of Frosen Thawed Semen of Bali Cattle Bull (Bos sondaicus). Buletin Peternakan, 42(4): 273-277.

Feradis. 2010. Bioteknologi Reproduksi Pada Ternak. Alfabeta, Bandung.

Garner, D. L dan E. S. E. Hafez. 2008. Spermatozoa and Seminal Plasma. Reproduction in Farm Animal. 7: 96109.

Gazali, M. S. dan T. Natal. 2002. Ulasan Kriopreservasi Spermatozoa. J. Hayati. 9: 27-32.

Hafez, E. S. E. 2000. Semen Evaluation. In: Reproduction In Farm Animals. 7 th Edition. Lippincott Wiliams and Wilkins. Maryland, USA.

Herdiawan. 2004. Pengaruh Laju Penurunan Suhu dan Jenis Pengencer Terhadap Kualitas Semen Beku Domba Pariangan. JITV. 9(2): 98-107.

Kwon, A. Y., H. J. Ko, and C. S. Park. 2002. Effect of Diluent Component, Freezing rate, thawing temperature on $\mathrm{AC}$ acrosom morphology, and motility of frozen thawed boar semen. Asian-Aust. J. Anim. Sci. 15: 247-249.

Lestari, S., D. M. Saleh, dan Maidaswar. 2013. Profil Kualitas Semen Segar Sapi Pejantan Limousin dengan Umur yang Berbeda di BIB Lembang Jawa Barat.

Laju Penurunan Suhu Terhadap ... (Suhartati et al.) 
J. Ilmiah Peternakan. 1(3): 1165-1172.

Mauda, D. B., U. Paputungan., M. N. Hendrik, dan S. H. Tarungan. 2017. Karakteristik semen segar sapi bangsa limousin dan simental di Balai Inseminasi Buatan Lembang. Jurnal Zootek. 37: 360-369.

Muhilal, dan A. Sulaiman. 2004. Angka Kecukupan Vitamin Larut Lemak. Di dalam Widyakarya Nasional Pangan dan Gizi VIII; Jakarta 17- 19 Mei 2004. Lembaga Ilmu Pengetahuan Indonesia, Jakarta.

Mumu, M. I. 2009. Viabilitas Semen Sapi Simental yang Dibekukan Menggunakan Krioprotektan Gliserol. J. Agroland. 16(2): 172-179.

Sagita, H. 2015. Pengaruh Percepatan Penurunan Suhu pada Medium Pengencer Tris Sitrat Susu Skim dan Tris Sitrat Kuning Telur terhadap Kualitas Semen Beku Post Thawing Sapi Brahman. Skripsi. Fakultas Peternakan, Universitas Andalas, Padang.

Sunami, S., N. Isnaini, dan S. Wahjuningsih. 2017. Kualitas Semen Segar dan Recovery Rate (Rr) Sapi Limousin pada Musim Yang Berbeda. J. Ternak Tropika. 18(1): 36-50.

Salamon, S. and W. M. C. Maxwell. 2000. Frozen storage of ram semen 1.Processing, freezing, thawing and fertility after cervical insemination. Anim. Reprod. Sci. 37: 85-249.

Suharyati, S. dan M. Hartono. 2011.
Preservasi dan Kriopreservasi Semen Sapi Limousin dalam Berbagai Bahan Pengencer. J. Kedokteran Hewan. 5(2).

Supriatna, I. dan H. P. Fachriyan. 1992. In Vitro Fertilisasi,Transfer Embrio dan pembekuan Embrio. PAU-Bioteknologi IPB. Bogor. hlm. 35-48.

Susilawati, T. 2011. Spermatology. UB Press. Universitas Brawijaya, Malang.

Steel, R. G. D. dan J. H. Torrie. 1991. Prinsip dan Prosedur Statistika Suatu Pendekatan Biometrik. Ed 2 Alih Bahasa B. Sumantri. PT. Gramedia Pustaka Utama, Jakarta.

Toelihere, M. R. 1993. Inseminasi Buatan Pada Ternak. Angkasa, Bandung.

Toelihere, M. R. 1993. Fisiologi Reproduksi Pada Ternak. Angkasa, Bandung.

Wahyudi, F. E., T. Susilawati, dan N. Isnaini. 2016. Penggantian bovine serum albumin pada CEP-2 dengan serum dara sapi Limousin pada suhu penyimpanan 3-5ㄷ. J. Ternak Tropika. 17(2): 8-15.

Yahaq, M. A., Y. S. Ondho, dan Sutiyono. 2019. Pengaruh Penambahan Vitamin $C$ dalam Pengencer Semen Sapi Limousin yang Dibekukan Terhadap Kualitas Post Thawing. Jurnal Sain Peternakan Indonesia. 14(4): 380-386.

Zulyazaini., Dasrul., S. Wahyuni., M. Akmal, dan M. A. N. Abdullah. 2016. Karakteristik Semen dan Komposisi Kimia Plasma Seminalis Sapi Aceh yang Dipelihara Di BIBD Saree Aceh Besar. Agripet. 16(2): 121-130. 